Document downloaded from:

http://hdl.handle.net/10251/136155

This paper must be cited as:

Llorens Molina, JA.; Ygueravide, B.; Vacas, S. (2019). Essential oil composition of berries of Juniperus oxycedrus L. ssp. oxycedrus according to their ripening stage. Journal of Essential Oil Research. 31(4):276-285. https://doi.org/10.1080/10412905.2019.1583140

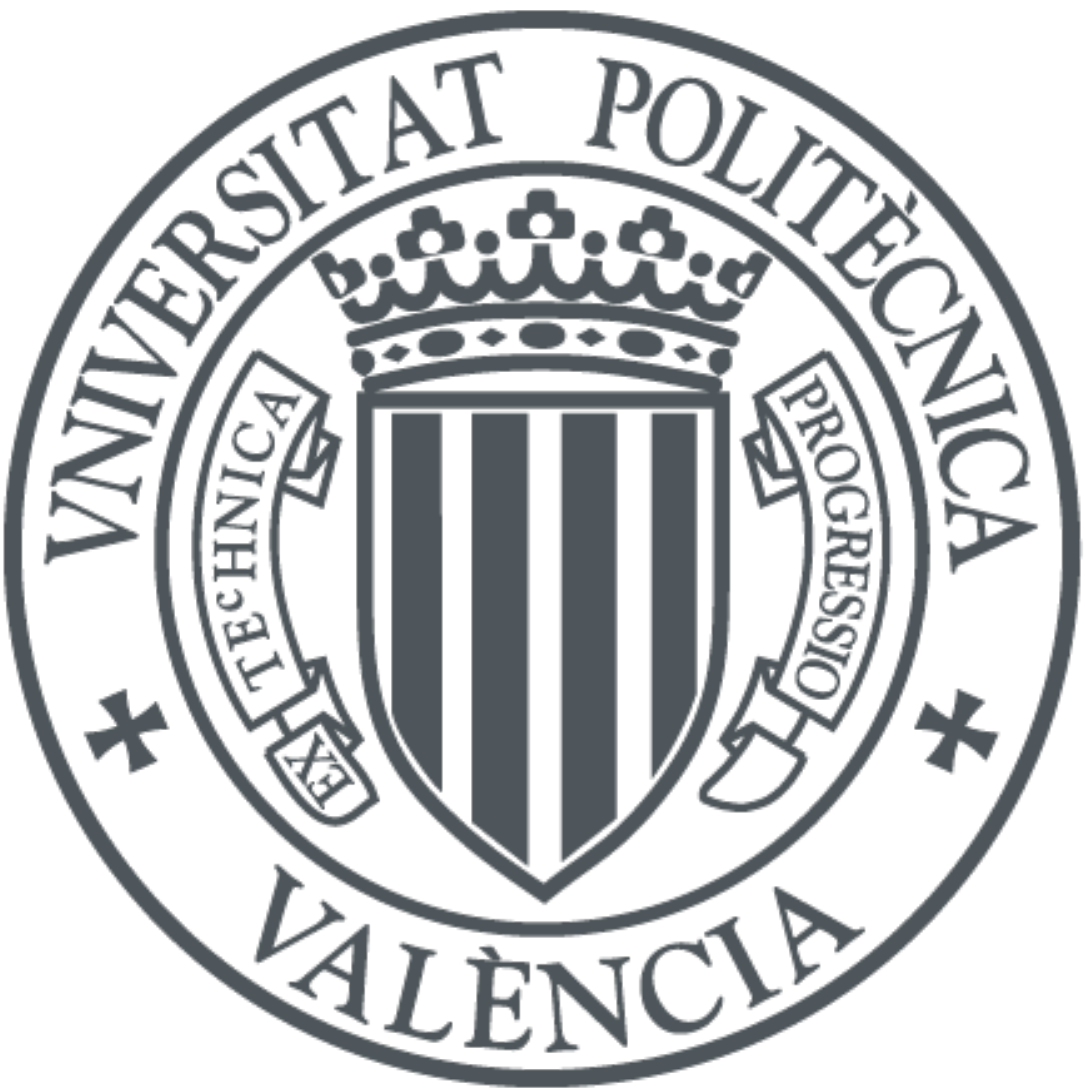

The final publication is available at

https://doi.org/10.1080/10412905.2019.1583140

Copyright Taylor \& Francis

Additional Information 


\title{
Essential oil composition of berries of Juniperus oxycedrus ssp. oxycedrus according their ripening stage
}

\author{
Juan A. Llorens-Molina*
}

Mediterranean Agroforestry Institute, Universitat Politècnica de València. Ed. 8F, Camí de Vera, s/n, 46022, València (Spain)

E-mail: juallom2@qim.upv.es; Tel.+0034671076678, ORCID: 0000-0002-8455-3010

Begoña Ygueravide

School of Agricultural Engineering and Environment, Universitat Politècnica de

València. Ed. 3P, Camí de Vera, s/n 46022, València (Spain)

E-mail: beygro@etsiamn.upv.es, Tel.+0034606429394

Sandra Vacas

Centre for Agricultural Chemical Ecology - Mediterranean Agroforestry Institute. Universitat Politècnica de València, Ed. 6C, Camí de Vera, s/n, 46022 València (Spain)

E-mail: sanvagon@ceqa.upv.es; Tel. +0034963879058; ORCID:0000-0001-6911-1647

*Corresponding author 


\title{
Essential oil composition of berries of Juniperus oxycedrus ssp. oxycedrus according their ripening stage
}

\author{
Juan A. Llorens-Molina ${ }^{\mathrm{a}}$, Begoña Ygueravide ${ }^{\mathrm{b}}$ \& Sandra Vacas ${ }^{\mathrm{c}}$ \\ ${ }^{a}$ Mediterranean Agroforestry Institute, Universitat Politècnica de València. Camí de \\ Vera, s/n, 46022, València (Spain) \\ ${ }^{\mathrm{b}}$ School of Agricultural Engineering and Environment, Universitat Politècnica de \\ València. \\ ${ }^{c}$ Centre for Agricultural Chemical Ecology (Mediterranean Agroforestry Institute). \\ Universitat Politècnica de València.
}

Some important essential oils (EOs) can be extracted from berries of different species and their composition depends on their maturation level. The main objective of this work was to relate the EO composition of Juniperus oxycedrus L ssp. oxycedrus berries with their ripening degree. For this purpose, a classification method based on the CIEL*a*b* colour measurement was applied. Once the samples were classified according their ripening stage, they were subjected to simultaneous distillation extraction (SDE) and gas chromatography (GC/FID and GC/MS). Among the total of 71 compounds identified, hydrocarbon monoterpenes constituted the most important fraction (42.8-89.8 $\%)$, mainly represented by $\alpha$-pinene (30.1-66.4 \%) and myrcene (6.1-34.8 \%). Hydrocarbon sesquiterpenes accounted for 4.0-26.4 \%, with germacrene-D (0.2$16.9 \%$ ) as the major component. The results of discriminant analysis proved that CIEL*a*b* implementation was useful to objectively classify the ripening stage. Regarding the EO chemical composition, statistically significant differences were observed in the proportion of myrcene and hydrocarbon monoterpenes, as well as the grouped oxygenated monoterpene, sesquiterpene and diterpene compounds, over the maturation process. In general, an increase in the proportion of oxygenated compounds was noted as maturation progressed. As for oil yield, the maximum was observed in the intermediate stages of ripening.Keywords: word; another word; lower case except names

Keywords: Juniperus oxycedrus L, berries, essential oils, ripening stage, colour 


\section{Introduction}

Juniperus oxycedrus L. ssp. oxycedrus (Cupressaceae) is an extended heliophilic and xerophilic shrub or small tree growing wild in stony areas from Mediterranean and Near East countries. In addition to its traditional use as food and beverages flavouring (1-4), many applications have been reported owing to its biological activity. The essential oil (EO) of berries of $J$. oxycedrus shows antioxidant activity (4-6), which explains its wellknown use as food preservative (7). Antifungal and antimicrobial activity have been also reported (6, 8- 10). Other researches deal with healthcare field: wounds healing (11), activity against protozoan parasites of the genus Leishmania (12) or antiproliferative activity in leukemia cells (13), as well as insecticidal activity like that reported against Sitophilus oryzae (14) or the larvicidal action against Culex pipiens (15).

With regard to EO chemical profile of berries, it is relatively homogeneous from a qualitative point of view. As referred by Boti et al. (16) in a chemotaxonomic study with samples from Corsica, these oils can be grouped according to their relative amounts of $\alpha$-pinene, myrcene and germacrene- $\mathrm{D}$. The major fraction is constituted by hydrocarbon monoterpenic compounds in which $\alpha$-pinene is usually the major compound, reaching up to $70.63 \%$ in ripe berries (9). This compound, together with myrcene, limonene and germacrene-D, are cited as major compounds in numerous samples from different geographical origins: Croatia (1), Sardinia (Italy) (9), Corsica (France) (16), Lebanon (5), Macedonia, (10) and Turkey $(17,18)$. Indeed, the bacteriostatic activity of this EO can be largely attributed to its $\alpha$-pinene content (19). Within these similar profiles, it is worth highlighting the predominance of myrcene in samples from Greece (14), Abruzzo (Italy) (20), and Kosovo (21). 
As for seasonal variations, significant differences were found between ripe and unripe berries affecting $\alpha$-pinene and myrcene amounts (9). In the same way, noticeable changes affecting mainly $\alpha$-pinene and germacrene-D were found by Salido et al. (22) comparing unripe and ripe berries in Juniperus oxycedrus ssp. badia. Bakkour et al. (23) have referred very significant changes between ripe and unripe berries of Juniperus excelsa affecting the amount of $\alpha$-pinene (major component), which shows a noteworthy increase in ripening berries and, in parallel, a decrease in oxygenated sesquiterpenic fraction ((E)-nerolidol and $(Z, E)$-farnesol, mainly).

Given that many EOs are extracted from fruits and seeds of different plant taxa, the relevance of possible changes in chemical composition due to ripening stage should be emphasized. Some representative examples belong to Juniperus and Myrtus genus, but others are also worth to mention as Illicium verum (star anise) or Elettaria cardamomum (cardamom). These changes, based on the simple visual appreciation of colour associated to seasonal development, have been reported for Myrtus communis L. (24-26). Nevertheless, since the maturation period lasts beyond one year in berries of Juniperus species, some ripening stages may co-occur not only in the same populations, but in the same individuals. This fact may contribute to hindering the possibility of taking the seasonal development as criterion for defining the ripening stages.

In order to use these EOs as source of bioactive molecules, their changes over maturation period should be well-known. For this purpose, they should be defined by means of measurable parameters, unlike the usual distinction between ripe and unripe berries exclusively established from a visual point of view. The aim of this work was to propose a colorimetric based methodology for an objective classification of Juniperus oxycedrus berries according their ripening stage, in such a way that it can be correlated with composition and yield of the EOs 


\section{Material and methods}

\section{Plant material}

Plant material was collected in December 2016 - January 2017 from three locations in Comunitat Valenciana (Spain): Segart, Lliria and Ahín. Three individuals were selected in each location in such a way that all the ripening range was represented. The

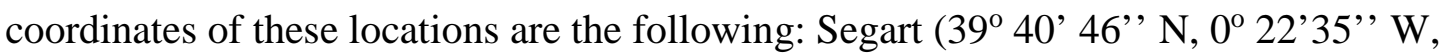
303 m a.s.l.), Lliria (39 37’38’’ N, 0 40’46’’ W, 183 m a.s.l.), Ahín (39 53’38’’ N, 0 21'26’' W, $765 \mathrm{~m}$ a.s.l.). Voucher specimens were lodged in the herbarium at the Mediterranean Agroforestry Institute (VALA) (Universitat Politècnica de València, Spain).

From the bioclimatic point of view, Segart and Lliria can be considered as thermo mediterranean zones (27), whereas Ahín as meso mediterranean zone (28).

\section{Selection of samples}

A first visual classification of ripening stages of berries was carried out according the following criteria (Figure 1):

A. Berries showing homogeneously green colour on its whole surface

B. Berries showing a mixed half-and-half green-brownish colour

C. Brown yellowish colour.

D. Berries homogenously brown-reddish colour on its whole surface.

E. Berries showing dark red -black colour. 
Figure 1. Visual ripening stages

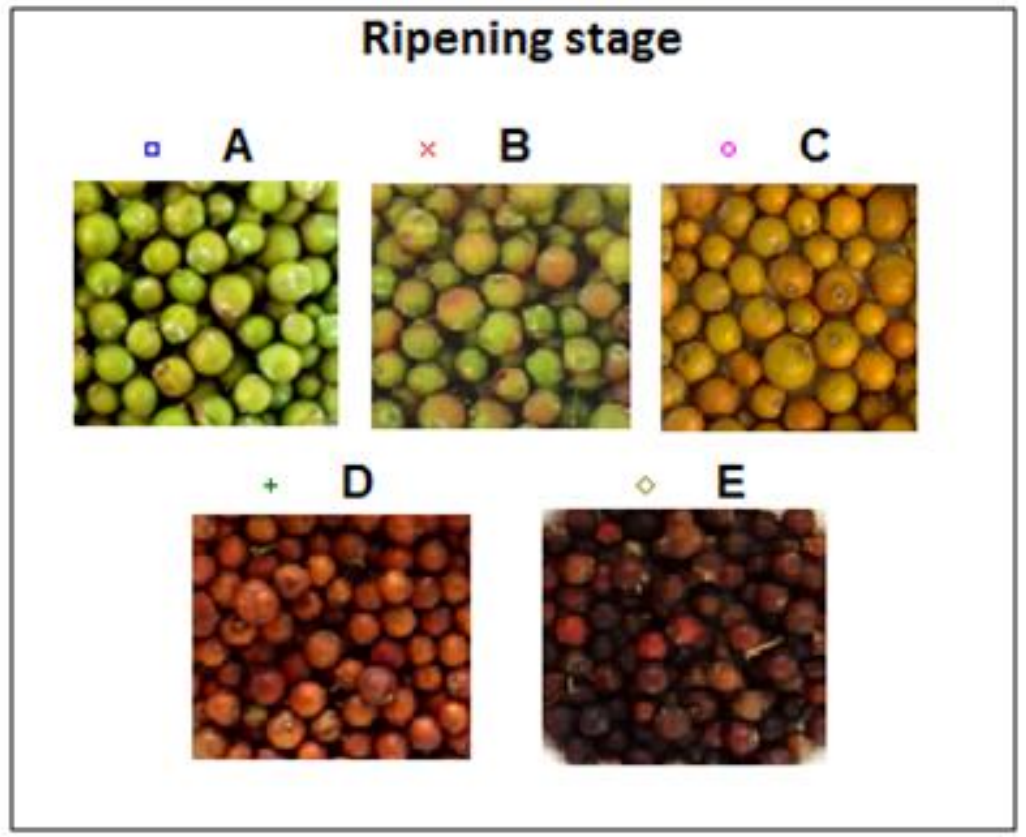

Five samples were separated from each ripening stage in order to carry out the CIE L*a*b* colour measurement (25 samples in total) $(29,30)$. This colorimetric method has been usually applied for classifying fruits and vegetables according their ripening level (31-33).

Ten measures of the variables: L* (lightness), a* (green-red) and b* (yellowblue) were registered by means of a colour reader CR-10 Plus (Konica Minolta ${ }^{\circledR}$ ). A one-way ANOVA analysis was applied to these measures in order to test the significance of differences in their values according the previously defined ripening stages.

Once the results from ANOVA analysis were considered, mean values for each sample were subjected to discriminant analysis in order to validate the visual grading and obtain the classification functions for applying them to possible new samples.

\section{Determination of moisture content}

In order to evaluate the yield as referred to dry material, the moisture content was 
determined in triplicate by drying $3 \mathrm{~g}$ samples for each of the five ripening stages up to constant weight (34), employing a vacuum oven (Vaciotem-T, JP Selecta, Spain) set at $30^{\circ} \mathrm{C}$.

\section{Essential Oil extraction}

$10 \mathrm{~g}$ of berries belonging to each one of the 25 samples were crushed with a domestic

mill just before being subjected for $3 \mathrm{~h}$ to simultaneous extraction distillation using a Likens-Nickerson type apparatus (35). The extracts were then dried with anhydrous sodium sulphate and evaporated under reduced pressure at room temperature. After adding $1.5 \mathrm{~mL}$ of dichloromethane, the extracts were kept in sealed chromatographic vials and stored at $-18^{\circ} \mathrm{C}$ until further analysis. The EO yield was determined based on dry weight of samples by addition of 1 or $2 \mu \mathrm{L}$ of tetradecane (Sigma-Aldrich ${ }^{\circledR}$ ) as internal standard, according to the weight of samples.

\section{GC and GC/MS Analysis}

The analysis of samples was carried out by GC-FID and GC-MS. A Clarus 500 GC (Perkin-Elmer Inc., Wellesley, PA, USA) chromatograph equipped with a flame ionization detector (FID) and capillary column ZB-5 (30 m $\times 0.25 \mathrm{~mm}$ i.d. $\times 0.25 \mu \mathrm{m}$ film thickness; Phenomenex Inc, Torrance, CA, USA) was used for quantitative analysis. The injection volume was $1 \mu \mathrm{L}$. The GC oven temperature was programmed from $50^{\circ} \mathrm{C}$ to $250^{\circ} \mathrm{C}$ at a rate of $3^{\circ} \mathrm{C} \mathrm{min}-1$. Helium was the carrier gas $(1.2 \mathrm{~mL}$ $\min -1)$. Injector and detector temperatures were set at $250^{\circ} \mathrm{C}$. The percentage composition of the EO was computed from GC peak areas without correction factors by means of the software Total Chrom 6.2 (Perkin-Elmer Inc., Wellesley, PA, USA). Analysis by GC-MS was performed using a Clarus 500 GC-MS apparatus equipped with the same capillary column, carrier and operating conditions described 
above for GC analysis. Ionization source temperature was set at $200^{\circ} \mathrm{C}$ and $70 \mathrm{eV}$ electron impact mode was employed. MS spectra were obtained by means of total ion scan (TIC) mode (mass range m/z 45-500 uma). The total ion chromatograms and mass spectra were processed with the Turbomass 5.4 software (Perkin-Elmer Inc.). Retention indices were determined by injection of C8-C25 n-alkanes standard (Supelco, Bellefonte, PE, USA) under the same conditions. The EO components were identified by comparison of calculated retention indices, high probability matches according to mass spectra computer library search (NIST MS 2.0) and available data from literature (36). Identification of the following compounds was also confirmed by comparison of their experimental lineal retention index (LRI) with those of authentic reference standards (Sigma-Aldrich, Madrid, Spain): $\alpha$-pinene, $\beta$-pinene, camphene, myrcene, limonene, (Z)- $\beta$-ocimene, camphor, terpinolene and terpinen-4-ol.

\section{Statistical processing of data}

One-way ANOVA analysis followed by multiple range test were applied to determine the significance of differences in colour parameters $\mathrm{L}^{*}, \mathrm{a}^{*}$ and $\mathrm{b}^{*}$ among samples, as well as in the yield and composition among ripening stages by means of Statgraphics Centurion XVI® (Statpoint Technologies, Inc.). Tukey's HSD (honest significant difference) test (at $\mathrm{P}<0.05$ ) was applied in order to evaluate the significance of the differences. Original percentage data were subjected to arcsin [square root $(\% / 100)$ ] transformation in order to fulfill the homocedasticity requirement.

To validate the classification of samples according their ripening stage based on colour, the mean values of variables for the 25 samples were subjected to a stepwise discriminant analysis based on Fisher's linear functions by means of Statgraphics 
Centurion XVI ${ }^{\circledR}$ software. This statistical tool allows understanding what differentiates the groups and predicting group belonging for unclassified objects.

\section{Results}

\section{Definition of ripening stages by CIEL*a*b* method}

The results of the one-way ANOVA applied to the measured values of $\mathrm{L}^{*}, \mathrm{a}^{*}$ and $\mathrm{b}^{*}$ are displayed in table 1.

Table 1. Values expressed as mean \pm standard deviation of $\mathrm{L}^{*}, \mathrm{a}^{*}$ and $\mathrm{b}^{*}$ according to the ripening stage (Values in the same row with different letters differ significantly for Tukey's test at $p<0.05$ )

Table 1 . Values expressed as mean \pm standard deviation of $\mathrm{L}^{*}, \mathrm{a}^{*}$ and $\mathrm{b}^{*}$ according the ripening stage (Values in the same row with different letters differ significantly for Tukey's test at $p<0.05$ )

Ripening stage

\begin{tabular}{llllll}
\hline Variable & A & B & C & D & E \\
L* & $-39.43 \pm 4.27 \mathrm{a}$ & $-41.68 \pm 5.24 \mathrm{ab}$ & $-42.17 \pm 3.69 \mathrm{~b}$ & $-43.79 \pm 13.26 \mathrm{~b}$ & $-49.67 \pm 2.2 \mathrm{c}$ \\
& & & & & \\
$\mathrm{a}^{*}$ & $-5.34 \pm 1.48 \mathrm{a}$ & $-1.31 \pm 2.84 \mathrm{~b}$ & $3.25 \pm 2.13 \mathrm{c}$ & $8.77 \pm 3.16 \mathrm{~d}$ & $3.04 \pm 2.26 \mathrm{c}$ \\
& & & & & \\
b* & $23.11 \pm 3.72 \mathrm{a}$ & $22.58 \pm 3.76 \mathrm{a}$ & $20.84 \pm 2.86 \mathrm{~b}$ & $14.82 \pm 2.84 \mathrm{c}$ & $11.06 \pm 0.92 \mathrm{~d}$
\end{tabular}


The parameter $b^{*}$ marks a clear distinction between the first two ripening stages (green berries and beginning of ripening with brown tones) and the rest (where the berries evolve from a yellowish brown to a dark red, almost black). Parameter a* provides complementary information when distinguishing the first two stages of maturation. On the other hand, the parameter $\mathrm{L} *$ marks a clear difference between the initial stage (A) and the last three ones (C, D and E), when berries have totally lost their green colour.

The result of discriminant analysis of the mean values of $\mathrm{L}^{*}$, a* and $\mathrm{b}^{*}$ of samples is displayed in Fig. 2 The two discriminant functions were statistically significant $(\mathrm{P}<0.05)$ with $\lambda$ (Wilks) values: 0.0063 and 0.1601 , respectively, accounting for $99.57 \%$ of total variance. The $100 \%$ of cases were well classified.

F1 and F2 were defined as follows:

$$
\begin{aligned}
& F 1=-0.0582 L^{*}+0.8340 a^{*}-0.5687 b^{*} \\
& F 2=0.6125 L^{*}+0.5367 a^{*}+0.7026 b^{*}
\end{aligned}
$$

As displayed in Fig. 2, F1 described the colour grading of stages A, B, C and D. The difference between these stages and E was explained by F2, in which this stage showed the lowest value.

Figure 2. Scatterplot of Discriminant Functions for ripening stages according the variables defining the colour. 


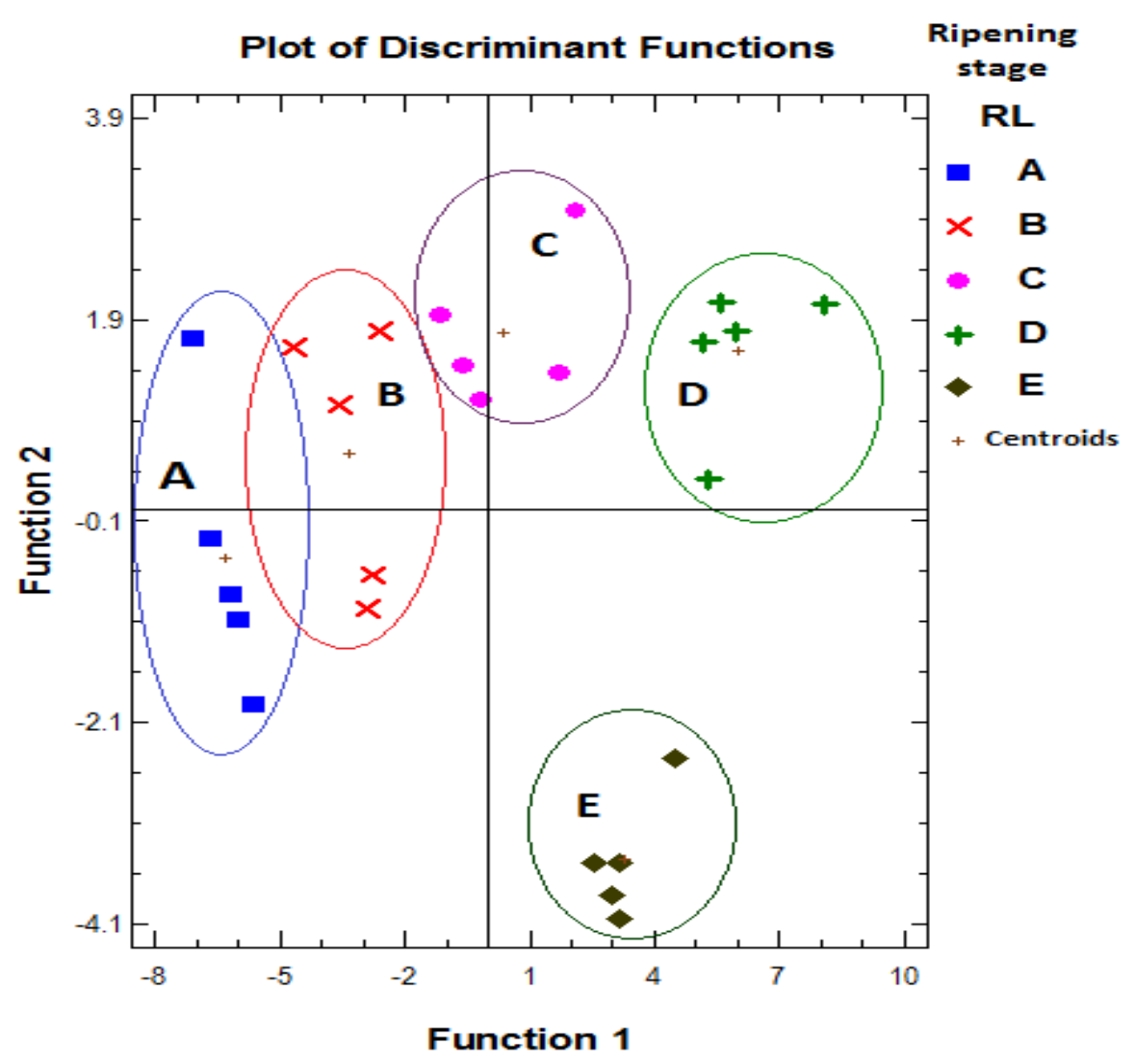

Yield and composition of EO according the ripening stage.

The composition of the EOs analysed is similar to the most extended profile reported in the literature. Seventy-one compounds were identified accounting for $95.0-99.8 \%$ of the total chromatogram. $\alpha$-pinene (30.1-66.5 \%), myrcene (6.1-34.3\%) and germacrene D (0.8-16.9 \%) were the major components. Some samples belonging to the last ripening stages also showed appreciable amounts of camphor (up to $6.4 \%$ ). Small, but not negligible (0.1-2.7 \%), was the contribution of the diterpenic fraction. Total ion chromatogram of a representative sample in which the main compounds are pointed out is displayed in Figure 3. The whole EO composition is shown in table 2. 
Table 2. Yield and composition of essential oil from berries of Juniperus oxycedrus ssp. Oxycedrus, according to their ripening stage.

Ripening stages

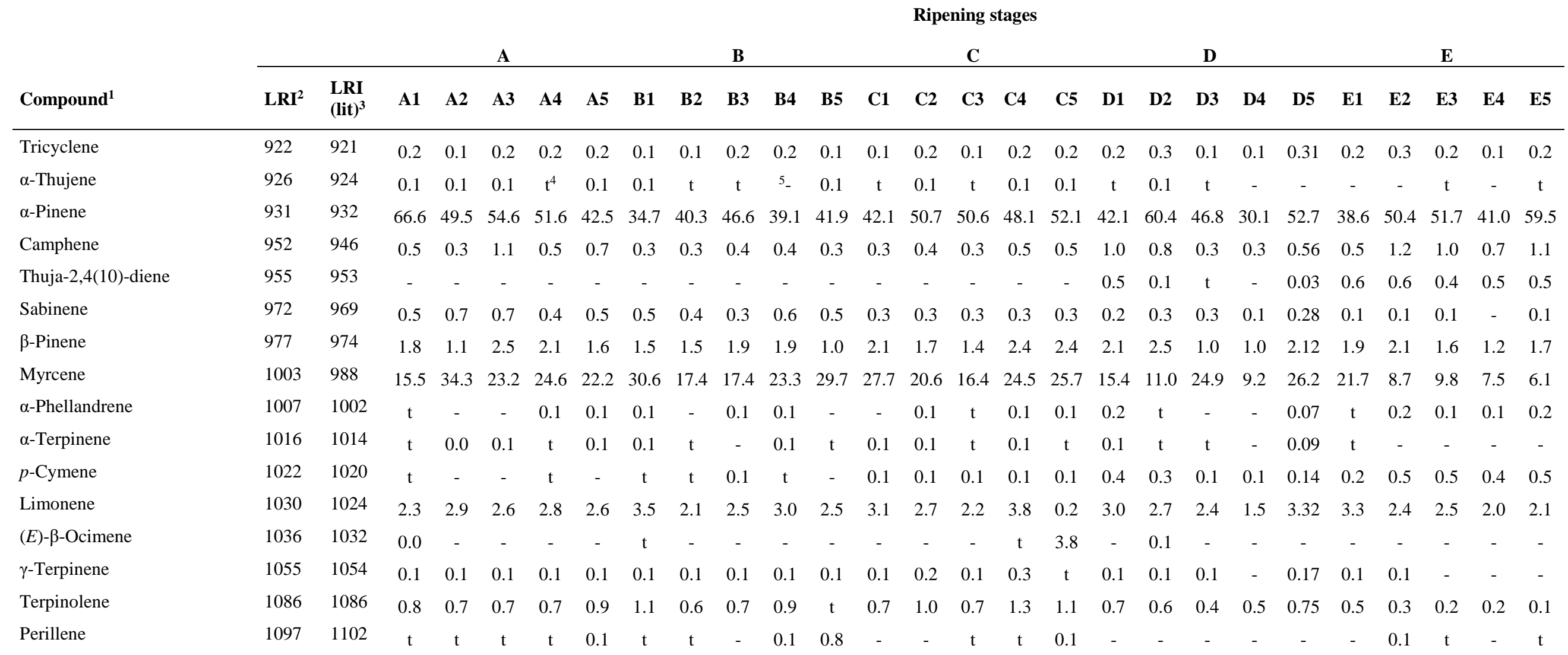

Hydrocarbon monoterpenes

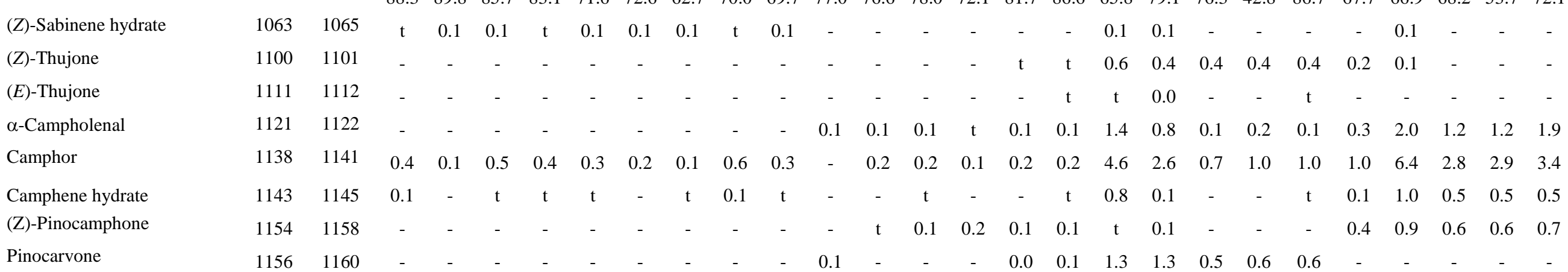


(E)-Pinocamphone

Terpinen-4-ol

p-Cymen-8-ol

$\alpha$-Terpineol

$\gamma$-Terpineol

Carvone

\section{Oxigenated monoterpenes}

$\alpha$-Cubenene

$\alpha$-Copaene

$\beta$-Elemene

$\beta$-Caryophyllene

$\beta$-Copaene

Bergamotene- $\alpha-<$ trans- $>$

Aromadendrene

(Z)-Muurola-3,5-diene

$\alpha$-Humulene

Sesquisabinene

$\gamma$-Gurgujene

Germacrene-D

$\gamma$-Amorphene

$\alpha$-Muurolene

$\gamma$-Cadinene

$\delta$-Cadinene

Cadina-1,4-diene- $<$ trans->

$\alpha$-Cadinene

$\alpha$-calacorene

\section{Hydrocarbon sesquiterpenes}

(E)-neronidol

Caryophyllene oxyde

Humulene epoxide (II)
$1167 \quad 1172$

$1173 \quad 1174$

$1181 \quad 1179$

$1186 \quad 1186$

11991199

$1238 \quad 1239$

$1347 \quad 1345$

$1371 \quad 1374$

$1386 \quad 1389$

$1415 \quad 1417$

$1424 \quad 1430$

$1431 \quad 1432$

$1438 \quad 1439$

$1450 \quad 1448$

$1451 \quad 1452$

$1462 \quad 1457$

$1472 \quad 1475$

$1490 \quad 1484$

$1494 \quad 1495$

$1499 \quad 1500$

$1515 \quad 1513$

$1523 \quad 1522$

$1529 \quad 1533$

$1534 \quad 1537$

$1538 \quad 1544$

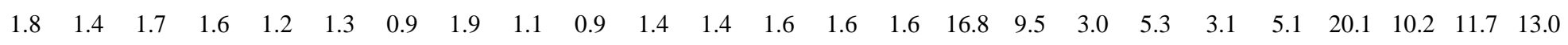
$\begin{array}{llllllllllllllllllllllllll}0.4 & 0.4 & 0.2 & 2.5 & 0.9 & 0.2 & 3.2 & 2.6 & 1.2 & 1.9 & 0.7 & 1.0 & 1.2 & 0.6 & 0.5 & 0.4 & 1.2 & 0.6 & 2.9 & 0.5 & 1.7 & 0.3 & 1.9 & 2.3 & 1.6\end{array}$

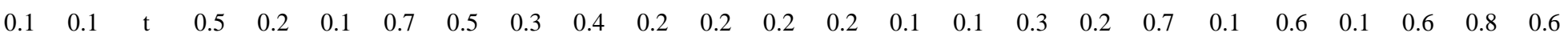
$\begin{array}{lllllllllllll}- & - & - & \mathrm{t} & \mathrm{t} & \mathrm{t} & 0.1 & 0.1 & \mathrm{t} & 0.1\end{array}$

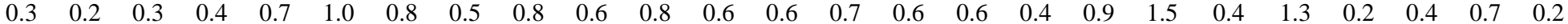
$\begin{array}{lllllllllllllllllllllllllllllllllllll}- & - & 0.1 & 0.1 & 0.1 & 0.2 & - & 0.1 & - & 0.1 & \mathrm{t} & - & \mathrm{t} & \mathrm{t} & - & - & 0.1 & 0.1 & \mathrm{t} & 0.1 & - & 0.1 & 0.1 & -\end{array}$

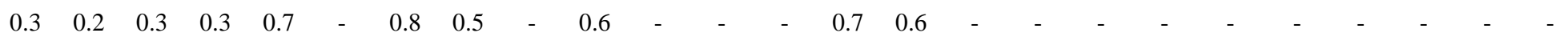

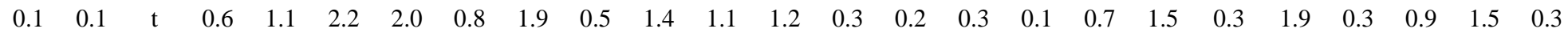
$\begin{array}{lllllllllllllllllllllllllllll}0.1 & \mathrm{t} & 0.1 & 0.1 & 0.1 & - & 0.2 & 0.1 & 0.1 & 0.1 & - & 0.2 & 0.3 & 0.1 & 0.1 & 0.1 & - & - & 0.3 & - & \mathrm{t} & 0.1 & 0.2 & 0.4 & 0.1\end{array}$ $\begin{array}{llllllllllllllllllllllllllll}0.1 & 0.1 & 0.1 & 0.2 & 0.2 & 0.1 & - & - & \mathrm{t} & 0.1 & 0.1 & 0.1 & 0.2 & 0.3 & 0.3 & - & 0.2 & - & 0.6 & - & 1.7 & 0.4 & 0.5 & 0.8 & 0.3\end{array}$ $\begin{array}{llllllllllllllllllllllllll}4.2 & 3.2 & 5.7 & 5.6 & 14.4 & 16.9 & 15.5 & 7.0 & 14.5 & 9.5 & 10.6 & 9.2 & 8.5 & 9.3 & 6.6 & 4.9 & 2.8 & 8.2 & 8.6 & 3.5 & 7.0 & 0.8 & 1.1 & 1.8 & 0.2\end{array}$ $\begin{array}{lllllllllllllllllllllllll}0.1 & 0.1 & 0.1 & 0.2 & 0.3 & 0.2 & 0.8 & 0.4 & 0.4 & 0.3 & 0.2 & 0.2 & 0.2 & 0.2 & 0.2 & 0.2 & 0.3 & 0.4 & 0.7 & 0.1 & 0.3 & 0.2 & 0.4 & 0.7 & 0.3\end{array}$ $\begin{array}{lllllllllllllllllllllllll}0.3 & 0.4 & 0.2 & 0.2 & 0.2 & 0.1 & 0.2 & 0.2 & 0.1 & 0.2 & 0.2 & 0.2 & 0.5 & \mathrm{t} & \mathrm{t} & 0.1 & 0.1 & 0.1 & 0.6 & 0.1 & 0.9 & 0.2 & - & - & -\end{array}$

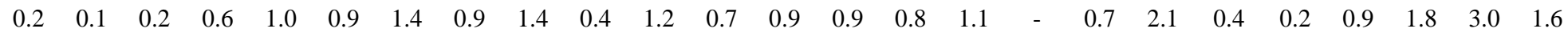
$\begin{array}{lllllllllllllllllllllllll}0.1 & 0.2 & 0.3 & 0.2 & 0.5 & 0.6 & 0.5 & 0.5 & 0.6 & 0.4 & 0.5 & 0.5 & 0.3 & 0.4 & 0.3 & 0.5 & 0.3 & 0.7 & 1.1 & 0.3 & 1.3 & 0.5 & 0.4 & 0.7 & 0.2\end{array}$ (1)

$\begin{array}{lllllllllllllllllllllllll}6.3 & 4.9 & 7.8 & 11.4 & 20.5 & 22.5 & 26.2 & 14.0 & 21.3 & 14.9 & 16.0 & 13.9 & 14.1 & 13.7 & 10.3 & 8.8 & 5.9 & 13.4 & 21.7 & 6.1 & 19.5 & 4.0 & 8.4 & 12.9 & 5.4\end{array}$ $\begin{array}{lllllllllllllllllllllllllll}1569 & 1561 & 0.3 & 0.2 & 1.2 & 3.8 & 1.1 & 2.1 & 5.2 & 4.2 & 1.6 & 0.4 & 3.4 & 7.5 & 1.6 & 0.9 & 1.5 & 1.1 & 1.8 & 5.9 & 0.9 & 0.3 & 1.7 & 5.4 & 7.6 & 1.5 & 1.5\end{array}$ $\begin{array}{llllllllllllllllllllllllllllll}1578 & 1582 & - & - & \mathrm{t} & \mathrm{t} & 0.1 & \mathrm{t} & 0.1 & 0.1 & 0.1 & 0.1 & \mathrm{t} & 0.1 & \mathrm{t} & \mathrm{t} & 0.8 & 0.2 & 0.7 & 1.3 & 0.3 & 1.1 & 1.0 & 0.8 & 1.4 & 0.4 & 0.4\end{array}$ $\begin{array}{llllllllllllllllllllllllllll}1605 & 1608 & - & - & \mathrm{t} & 0.1 & 0.1 & - & 0.1 & 0.1 & \mathrm{t} & 0.2 & \mathrm{t} & 0.1 & \mathrm{t} & - & 0.8 & 0.2 & 0.4 & 1.7 & 0.2 & 0.7 & 0.9 & 0.7 & 1.3 & 0.3 & 0.3\end{array}$ 
Cubenol $<1$ - epi- $>$

Cadinol-epi- $\alpha$

Muurolol <-epi- $\alpha>$

Selin-11-en-4 $\alpha$-ol

Bisabonol-<epi- $\beta>$

Bisabonol-<epi- $\alpha>$

\section{Oxigenated sesquiterpenes}

Rosa-5,15-diene -ent-

19281933

Sandaracopimara-8(14),15-

diene

Abietatriene

Hydrocarbon diterpenes

Geranyl linanol $<$ Z,Z $>$

Manoyl oxide

Sandaracopimarinal

Oxigenated diterpenes

2-Nonanone

Tridecane

Hexadecane

Heptadecane

Octadecane

Nonadecano

Other

Total identified

2 Temperature-programmed LRI referred to $n$-alkanes, determined on a DB5 capillary column.

${ }^{3}$ LRI Values coming from R.P. Adams (35)

${ }^{4}$ Percentage values less than $0.1 \%$ are denoted as $t$ (traces)

${ }^{5}$ No detected.

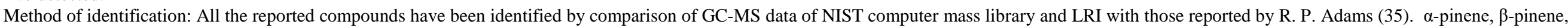
myrcene, $\alpha$-terpinene, $p$-Cymene, limonene, terpinolene, $(Z)$-thujone, $(E)$-thujone, camphor and terpinen-4-ol were identified by comparison of LRI with those of authentic samples.

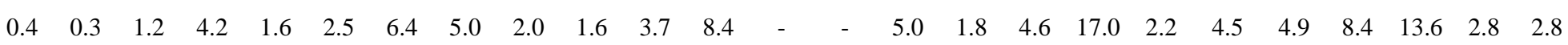

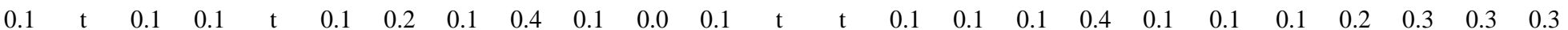
$\begin{array}{lllllllllllllllllllllllllll}0.1 & 0.1 & 0.1 & 0.3 & 0.1 & 0.4 & 0.4 & 0.2 & 0.4 & 0.2 & 0.1 & 0.2 & 0.0 & \mathrm{t} & 0.1 & 0.1 & 0.1 & 0.6 & 0.1 & 0.1 & 0.1 & 0.2 & 0.4 & 0.3 & 0.3\end{array}$ $\begin{array}{lllllllllllllllllllllllllllll}- & 0.0 & 0.0 & - & - & \mathrm{t} & 0.1 & 0.1 & \mathrm{t} & - & - & - & \mathrm{t} & - & - & 0.1 & - & 0.1 & 0.1 & \mathrm{t} & 0.1 & \mathrm{t} & \mathrm{t}\end{array}$

$\begin{array}{llllllllllllllllllllllllll}0.1 & 0.6 & 0.2 & 0.8 & 0.9 & 1.6 & 1.6 & 1.4 & 0.1 & 1.9 & 0.1 & 0.1 & 0.1 & \mathrm{t} & 2.0 & 0.8 & 0.5 & 2.1 & 0.3 & 0.3 & 1.7 & 1.2 & 2.0 & 1.1 & 1.1\end{array}$ $\begin{array}{lllllllllllllllllllllllllllllllll}1090 & 1087 & - & - & - & - & - & - & - & - & - & - & - & - & - & \mathrm{t} & 0.3 & 0.1 & - & - & - & 0.1 & 0.4 & 0.3 & 0.2 & 0.3 & 0.3\end{array}$ $\begin{array}{llllllllllllllllllllllllllll}1298 & 1300 & 1.1 & 0.7 & 0.7 & 0.3 & 0.3 & 0.4 & 0.6 & 0.3 & 0.6 & 0.5 & 0.7 & 0.8 & 0.1 & 0.1 & 0.4 & 0.8 & 0.5 & 1.8 & 0.4 & 0.4 & 0.6 & 1.0 & 1.0 & 1.5 & 1.5\end{array}$

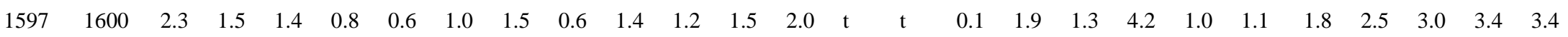
$\begin{array}{llllllllllllllllllllllllllllll}1692 & 1700 & 0.2 & 0.1 & 0.1 & 0.1 & \mathrm{t} & 0.1 & 0.1 & \mathrm{t} & 0.3 & 0.1 & 0.1 & 0.1 & - & - & - & 0.1 & 0.1 & 0.3 & 0.1 & - & 0.1 & 0.2 & \mathrm{t} & 0.3 & 0.3\end{array}$ $\begin{array}{lllllllllllllllllllllllllllll}1792 & 1800 & 0.6 & 0.4 & 0.4 & 0.2 & 0.2 & 0.2 & 0.3 & 0.1 & - & 0.3 & 0.4 & 0.5 & - & - & 0.2 & 0.4 & 0.3 & 1.0 & 0.2 & 0.2 & 0.3 & 0.5 & 0.5 & 0.8 & 0.8\end{array}$

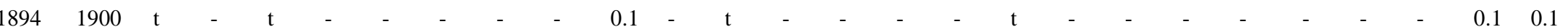

$\begin{array}{lllllllllllllllllllllllll}3.1 & 2.0 & 1.9 & 1.00 & 0.8 & 1.3 & 1.9 & 0.7 & 1.8 & 1.5 & 2.1 & 2.6 & 0.0 & 0.0 & 0.3 & 2.5 & 1.6 & 5.5 & 1.3 & 1.3 & 2.2 & 3.1 & 3.5 & 4.6 & 6.4\end{array}$

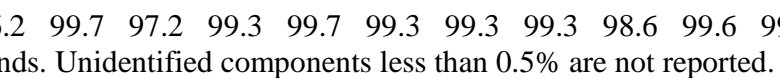


Figure 3. MS total ion chromatogram from a representative sample of berries of Juniperus oxycedrus ssp. oxycedrus EO

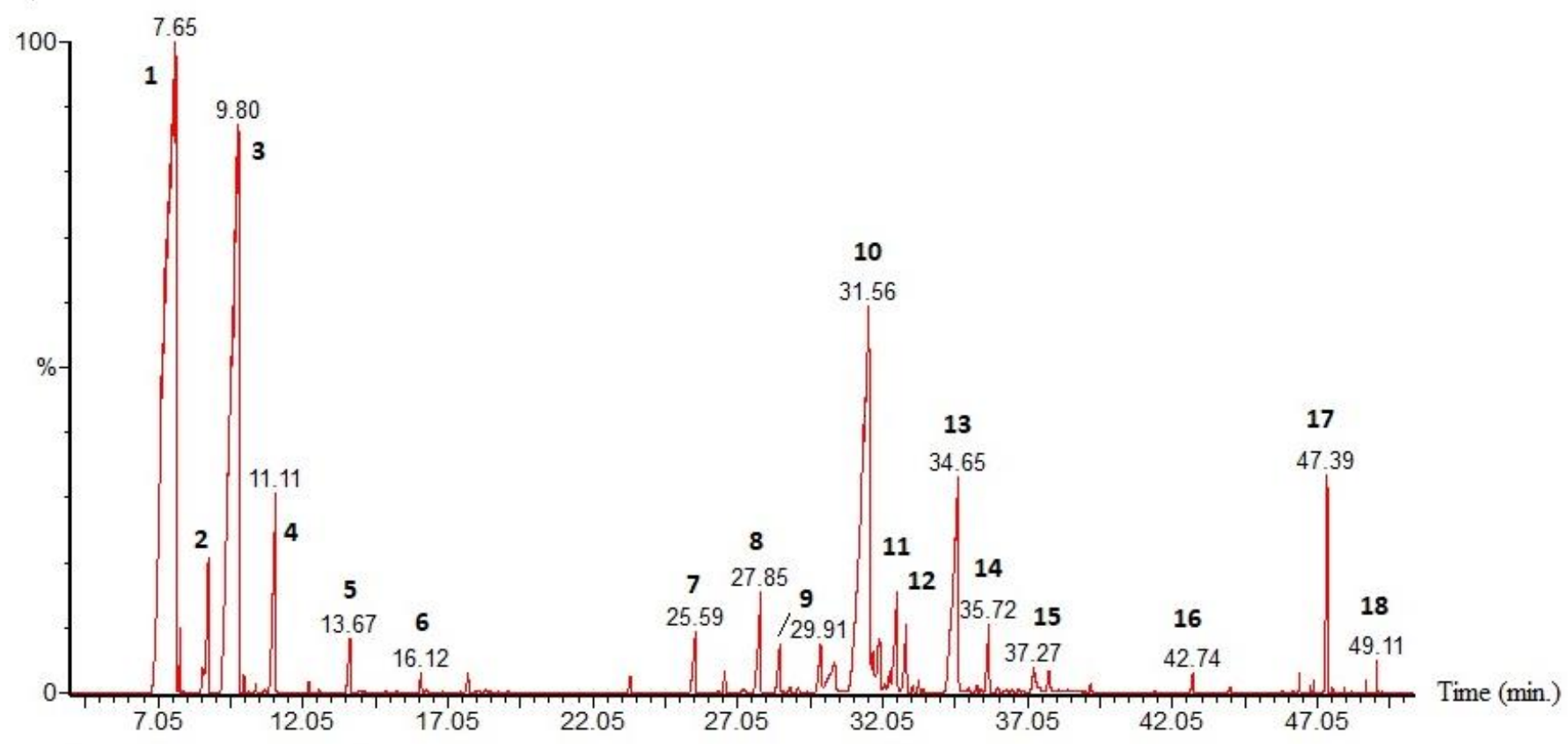

$1 \alpha$-pinene; 2 myrcene; $3 \beta$-pinene; 4 limonene; 5 terpinolene; 6 camphor; $7 \alpha$-cubebene ; 8 tetradecane; $9 \beta$-caryophyllene; 10 germacrene-D; $11 \gamma$-cadinene; $12 \delta$-cadinene; $13(E)$-nerolidol; 14 hexadecane; 15 murolol $<$ epi- $\alpha>; 16$ octadecane 17 manoyl oxide; 18 sandaracopiraminal.

Mean values \pm standard deviation and significant differences for the main compounds and grouped compounds are displayed in table 3. The optimum yield (regarding dry weight of crushed berries) was achieved at the beginning of ripening (when berries are changing from green to brown), showing balanced results for A, C and D stages. On the contrary, a noticeable decrease is observed in the dark berries (E). 
Table 3. Yield and EO composition throughout the ripening process.

Yield

$\alpha$-pinene

Myrcene

Limonene

Hydrocarbon

monoterpenes

Oxigenated

monoterpenes

Germacrene-D

Hydrocarbon

sesquiterpenes

Oxigenated

sesquiterpenes

Hydrocarbon

diterpenes

Oxigenated

diterpenes

No oxigenated

compounds

Oxigenated

compounds

\begin{tabular}{lllll}
$\mathrm{A}$ & $\mathrm{B}$ & $\mathrm{C}$ & $\mathrm{D}$ & $\mathrm{E}$ \\
\hline $1,6 \pm 0,4 \mathrm{a}$ & $2,3 \pm 0,6 \mathrm{~b}$ & $1,8 \pm 0,6 \mathrm{ab}$ & $1,6 \pm 0,4 \mathrm{a}$ & $0,8 \pm 0,2 \mathrm{c}$ \\
$53.0 \pm 8.8 \mathrm{a}$ & $40.5 \pm 4.3 \mathrm{~b}$ & $48.7 \pm 4.0 \mathrm{ab}$ & $46.4 \pm 11.4 \mathrm{ab}$ & $48.2 \pm 8.5 \mathrm{ab}$ \\
$24.0 \pm 6.7 \mathrm{a}$ & $23.7 \pm 6.4 \mathrm{a}$ & $23.0 \pm 4.5 \mathrm{a}$ & $17.3 \pm 7.8 \mathrm{ab}$ & $10.8 \pm 6.3 \mathrm{~b}$ \\
$2.6 \pm 0.2 \mathrm{a}$ & $2.7 \pm 0.6 \mathrm{a}$ & $2.4 \pm 1.4 \mathrm{a}$ & $2.6 \pm 0.7 \mathrm{a}$ & $2.5 \pm 0.5 \mathrm{a}$ \\
& & & & \\
$83.8 \pm 7.2 \mathrm{a}$ & $70.5 \pm 5.2 \mathrm{bc}$ & $79.0 \pm 5.4 \mathrm{ab}$ & $70.2 \pm 17.0 \mathrm{bc}$ & $65.8 \pm 7.0 \mathrm{c}$ \\
$1.5 \pm 0.3 \mathrm{a}$ & $1.2 \pm 0.4 \mathrm{a}$ & $1.5 \pm 0.1 \mathrm{a}$ & $7.5 \pm 5.8 \mathrm{~b}$ & $12.0 \pm 5.4 \mathrm{c}$ \\
$6.6 \pm 4.5 \mathrm{a}$ & $12.7 \pm 4.2 \mathrm{~b}$ & $8.8 \pm 1.5 \mathrm{ab}$ & $5.6 \pm 2.7 \mathrm{ac}$ & $2.7 \pm 2.9 \mathrm{c}$ \\
$7.7 \pm 5.0 \mathrm{a}$ & $15.5 \pm 5.6 \mathrm{~b}$ & $10.6 \pm 1.7 \mathrm{ab}$ & $7.6 \pm 4.0 \mathrm{a}$ & $5.4 \pm 4.1 \mathrm{a}$ \\
$1.3 \pm 1.8 \mathrm{a}$ & $3.5 \pm 2.1 \mathrm{abc}$ & $4.7 \pm 3.5 \mathrm{ab}$ & $6.1 \pm 6.2 \mathrm{bc}$ & $6.9 \pm 4.3 \mathrm{c}$ \\
& & & & \\
$0.2 \pm 0.1 \mathrm{a}$ & $0.3 \pm 0.2 \mathrm{a}$ & $0.1 \pm 0.1 \mathrm{a}$ & $0.2 \pm 0.2 \mathrm{a}$ & $0.2 \pm 0.1 \mathrm{a}$ \\
& & & & \\
$0.4 \pm 0.3 \mathrm{ab}$ & $1.1 \pm 0.7 \mathrm{ab}$ & $0.4 \pm 0.8 \mathrm{a}$ & $1.2 \pm 0.9 \mathrm{~b}$ & $1.3 \pm 0.7 \mathrm{~b}$ \\
$94.5 \pm 3.3 \mathrm{a}$ & $88.0 \pm 5.8 \mathrm{ab}$ & $91.4 \pm 3.1 \mathrm{a}$ & $81.0 \pm 12.1 \mathrm{bc}$ & $75.2 \pm 6.8 \mathrm{c}$ \\
$3.3 \pm 1.8 \mathrm{a}$ & $5.9 \pm 2.8 \mathrm{a}$ & $4.8 \pm 3.5 \mathrm{a}$ & $14.9 \pm 8.9 \mathrm{~b}$ & $20.4 \pm 7.4 \mathrm{~b}$
\end{tabular}

Values with different letter for the same row are significantly different (Tukey HSD, $\mathrm{P} \leq 0.05$ )

\section{Discussion}

As for the hydrocarbon monoterpene fraction, $\alpha$-pinene shows its highest proportion in the green berries, with a significant decrease at the beginning of ripening (Table 3). Further ripening stages maintain stable values for this compound. These changes agree with those reports by Angioni et al. (9) if unripe/ripe is related to stages B and C, respectively. This comment can be extended to hydrocarbon monoterpene fraction as a whole. However, myrcene showed a different profile, with a progressive decrease becoming significant at the last two ripening stages (Table 3). This decrease is also reported for myrcene in the aforementioned research from unripe to ripe stages.

Germacrene-D is by far the most important component of hydrocarbon sesquiterpene fraction. It achieves its highest proportion when berries begin to ripe (stage B), showing a significant decrease at the end (Table 3). The most regular change is observed in the oxygenated sesquiterpene compounds, showing a significantly progressive increase from the first to the last ripening stage. 
In spite of the high variability in the measurement of the colour parameters due to the small size of the berries, the parameters $\mathrm{L}^{*}$ and, mainly, $\mathrm{a}^{*}$ and $\mathrm{b}^{*}$, can be useful to define objectively a colour rank associated to the ripening process.

The ripening process in $J$. oxycedrus ssp. oxycedrus implies a progressive increase in the proportion of oxygenated compounds, both monoterpenic and sesquiterpenic ones. The most influencing compound in this tendency is myrcene, showing a noticeable decrease at the end of ripening process. On the other hand, the yield data show a maximum value at the beginning of maturation, whereas only the extremely mature berries have a very poor yield.

These results evidence that an intuitive classification based on purely visual criteria is not enough to clearly define the ripening stages and correlate them with the yield and chemical composition of berry EOs. Neither can the sampling time be adopted as a criterion, since given the duration of the maturation process, berries with different degrees of maturity can coexist in the same individual.

An objective definition of maturation stages based on the measurement of physical parameters, such as colour, can help optimize yield and composition of this type of EOs according to the type of biological activity implied. On the other hand, from the chemotaxonomic point of view, as it happens relating with the rest of variability sources, the correct definition of chemotypes requires controlling the degree of ripening, since the variations observed in major compounds could be, in that respect, relevant.

\section{References}

1. M. Milos and A. Radonic, Gas chromatography mass spectral analysis of free and glycosidically bound volatile compounds from Juniperus oxycedrus L. growing wild in Croatia, Food chemistry, 68(3), 333-338, (2000).

2. S. Burt, Essential oils: their antibacterial properties and potential applications in foods—a review, International journal of food microbiology, 94(3), 223-253, (2004).

3. H. Medini, A. Elaissi, M. Khouja, I. Chraief, F. Farhat, M. Hammami and F. Harzallah-Skhiri, Leaf essential oil of Juniperus oxycedrus L.(Cupressaceae) harvested in Northern Tunisia: composition and intra-specific variability, Chemistry and Biodiversity, 7(5), 1254-1266, (2010). 
4. H. Guenane, A. Gherib, B. Bakchiche, A. Carbonell-Barrachina, F. Hernández and M. Cano-Lamadrid, Antioxidant capacity, mineral content and essential oil composition from select Algerian medicinal plants, Scientific Study \& Research. Chemistry \& Chemical Engineering, Biotechnology, Food Industry, 18(3), 275-289, (2017).

5. M. R. Loizzo, R. Tundis, F. Conforti, A. Saab, G. A. Statti and F. Menichini, Comparative chemical composition, antioxidant and hypoglycaemic activities of Juniperus oxycedrus ssp. oxycedrus L. berry and wood oils from Lebanon, Food Chemistry, 105(2), 572-578, (2007).

6. B. Abdennaji, R. Nezha, R. Abderrahmane, R. Hafida, C. H. Halima, F. A. Danilo, P. R. Silvia and M. A, Bruno, Chemical Composition, Antioxidant and Antibacterial Activity of Juniperus oxycedrus subsp. oxycedrus L. berry, essential oil from Morocco. Journal of Applied Chemistry and Environment Protection, 1(1), (2017).

7. S. Cosentino, A. Barra, B. Pisano, M. Cabizza, F. M. Pirisi and F. Palmas, Composition and antimicrobial properties of Sardinian Juniperus essential oils against foodborne pathogens and spoilage microorganisms, Journal of food protection, 66(7), 1288-1291, (2003).

8. V. Stassi, E. Verykokidou, A. Loukis, C. Harvala and S. Philianos, The antimicrobial activity of the essential oils of four Juniperus species growing wild in Greece, Flavour and fragrance journal, 11(1), 71-74 (1996).

9. A. Angioni, A. Barra, M. T. Russo, V. Coroneo, S. Dessí and P. Cabras, Chemical composition of the essential oils of Juniperus from ripe and unripe berries and leaves and their antimicrobial activity, Journal of Agricultural and Food Chemistry, 51(10), 3073-3078, (2003).

10. F. Sela, M. Karapandzova, G. Stefkov, I. Cvetkovikj, E. Trajkovska-Dokikj, A. Kaftandzieva and S. Kulevanova, Chemical composition and antimicrobial activity of berry essential oil of Juniperus oxycedrus L.(Cupressaceae) grown wild in Republic of Macedonia, Macedonian Pharmaceutical Association, Marshal Tito 13b/8, Skopje Macedonia, 41, (2013).

11. I. Tumen, I. Süntar, H. Keleş and E. Küpeli Akkol, A therapeutic approach for wound healing by using essential oils of cupressus and juniperus species growing in Turkey, Evidence-based complementary and alternative medicine, (2012).

12. M. Machado, G. Santoro, M. C. Sousa, L. Salgueiro and C. Cavaleiro, Activity of essential oils on the growth of Leishmania infantum promastigotes, Flavour and fragrance journal, 25(3), 156-160, (2010).

13. A. M. Saab, H. Gali-Muhtasib, S. Maietti, A. Grandini, D. Rossi, I. Lampronti and R. Gambari, Comparative antiproliferative activities of wood and seeds essential oils of Juniperus oxycedrus L. against K562 human chronic myelogenous leukemia cells, Journal of Essential Oil Research, 26(4), 301-307, (2014). .

14. C. G. Athanassiou, N. G. Kavallieratos, E. Evergetis, A. M. Katsoula and S. A. Haroutounian, Insecticidal efficacy of silica gel with Juniperus oxycedrus ssp. oxycedrus (Pinales: Cupressaceae) 
essential oil against Sitophilus oryzae (Coleoptera: Curculionidae) and Tribolium confusum (Coleoptera: Tenebrionidae), Journal of economic entomology, 106(4), 1902-1910, (2012).

15. F. Vourlioti-Arapi, A. Michaelakis, E. Evergetis, G. Koliopoulos and S. A. Haroutounian, Essential oils of indigenous in Greece six Juniperus taxa, Parasitology Research, 110(5), 1829-1839, (2012).

16. J. B. Boti, A. Bighelli, C. Cavaleiro, L. Salgueiro and J. Casanova, Chemical variability of Juniperus oxycedrus ssp. oxycedrus berry and leaf oils from Corsica, analysed by combination of GC, GC-MS and 13C-NMR, Flavour and fragrance journal, 21(2), 268-273, (2006).

17. S. Hayta and E. Bagci, Essential oil constituents of the leaves, bark and cones of Juniperus oxycedrus subsp. oxycedrus L. from Turkey, Acta Botanica Gallica, 161(2), 201-207, (2014).

18. S. Alan, M. Kürkçüoğlu and G. Şener, Composition of the Essential Oils of Juniperus oxycedrus L. subsp. oxycedrus Growing in Turkey, Turkey Journal of Pharmaceuthical Science, 13(3), 300-303, (2016)

19. A. M. Leite, E. D. O. Lima, E. L. D. Souza, M. D. Diniz, V. Trajano and I. A. D. Medeiros, Inhibitory effect of beta-pinene, alpha-pinene and eugenol on the growth of potential infectious endocarditis causing Gram-positive bacteria, Revista Brasileira de Ciências Farmacêuticas, 43(1), 121-126, (2007).

20. G. Valentini, B. Bellomaria, F. Maggi and A. Manzi, The leaf and female cone oils of Juniperus oxycedrus L. ssp. oxycedrus and J. oxycedrus ssp. macrocarpa (Sibth. et Sm.) Ball. from Abruzzo, Journal of Essential Oil Research, 15(6), 418-421, (2003).

21. A. Hajdari, B. Mustafa, V. Gashi, D. Nebija, A. Ibraliu and J. Novak, Chemical composition of the essential oils of ripe berries of Juniperus oxycedrus L., growing wild in Kosovo, Biochemical Systematics and Ecology, 57, 90-94, (2014).

22. S. Salido, J. Altarejos, M. Nogueras, A. Sánchez, C. Pannecouque, M. Witvrouw and E. De Clercq, Chemical studies of essential oils of Juniperus oxycedrus ssp. badia, Journal of Ethnopharmacology, 81(1), 129-134, (2002).

23. Y. Bakkour, N. El-Achi, M. Tabcheh, H. El-Nakat and F. El Omar, Chemical composition and antioxidant activities of the essential oils from green and ripe berries of Juniperus excelsa growing in Lebanon, International Journal of Pharmacy \& Life Sciences, 4(2), (2013).

24. M. H. Boelens and R. Jimenez, The chemical composition of Spanish myrtle oils. Part II, Journal of Essential Oil Research, 4(4), 349-353, (1992).

25. P. C. Pereira, M. J. Cebola and M. G. Bernardo-Gil, Evolution of the yields and composition of essential oil from Portuguese myrtle (Myrtus comunis L.) through the vegetative cycle, Molecules, 14(8), 3094-3105, (2009).

26. W. A. Wannes, B. Mhamdi and B. Marzouk, Variations in essential oil and fatty acid composition during Myrtus communis var. italica fruit maturation, Food Chemistry, 112(3), 621-626, (2009).

27. M. Costa, Pisos bioclimáticos y series de vegetación en el área valenciana, Cuadernos de geografía, 31, 129-144, (1982). 
28. M. Costa, A. Aguilella, P. Soriano, J. Guemes, L. Mulet, J. Riera and C. Fabregat, Vegetacion y flora de la Sierra de Espadán. Ed. Fundación Bancaja, Valencia (Spain), (2005).

29. Identifying Colour Differences Using $\mathrm{L} * \mathrm{a} * \mathrm{~b} *$ or $\mathrm{L} * \mathrm{C} * \mathrm{H} *$ Coordinates, https://sensing.konicaminolta.us/blog/identifying-colour-differences-using-l-a-b-or-l-c-hcoordinates/, (10 february 2018).

30. A. Chiralt Boix, N. Martinez Navarrete, C. Gonzalez Martinez, P. Talens Oliag and G. Moraga Ballesteros, Propiedades físicas de los alimentos, Ed. Universitat Politècnica de València. Valencia, (2007).

31. R. Gómez-Ladrón de Guevara, J. E. Pardo-González, R. Varón-Castellanos and F. Navarro-Albaladejo, Evolution of colour during the ripening of selected varieties of paprika pepper (Capsicum annuum L.). Journal of agricultural and food chemistry, 44(8), 2049-2052, (1996).

32. A. López Camelo and P. A. Gómez, Comparison of colour indexes for tomato ripening, Horticultura Brasileira, 22(3), 534-537, (2004).

33. A. Ferrer, S. Remón, A. I. Negueruela and R. Oria, Changes during the ripening of the very late season Spanish peach cultivar Calanda: feasibility of using CIELAB coordinates as maturity indices, Scientia Horticulturae, 105(4), 435-446, (2005).

34. L. M. Nollet and M. Dekker, Analysis Handbook of Food, Food Science and Technology, (77), (1996).

35. R. P. Adams, Identification of essential oil components by gas chromatography/mass spectrometry. 5 online ed. Texensis Publishing, (2017).

36. A. Chaintreau, Simultaneous distillation-extraction: from birth to maturity, Flavour and fragrance journal, 16(2), 136-148, (2001). 